RAP CONFERENCE PROCEEDINGS, VOL. 5, PP. 64-67, 2020

ISSN 2737-9973 (ONLINE)| DOI: 10.37392/RAPPROC.2020.15

RAP-PROCEEDINGS.ORG

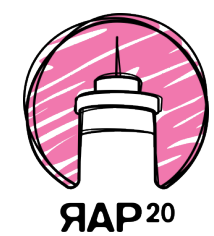

\title{
ANTIMICROBIAL ACTIVITY AND REDOX PROPERTY OF Ni(II) COMPLEXES WITH ORTHO- AND META-DIPHENOL DERIVATIVES
}

\section{K.A. Nabebina ${ }^{1,2^{*}}$, N.V. Loginova, ${ }^{1,2}$, T.V. Kovalchuk-Rabchinskaya', G.A. Ksendzova², N.P. Osipovich ${ }^{2}$}

\author{
${ }^{1}$ Belarusian State University, Minsk, Republic of Belarus \\ ${ }^{2}$ Research Institute for Physical-Chemical Problems, Minsk, Republic of Belarus
}

\begin{abstract}
The redox-activity of novel bioactive Ni(II) complexes with ortho- and meta-diphenols was investigated. Amorphous water insoluble complexes with general formula NiL2 were synthesized according to the authorial method. It was found that the complexes are highly lipophilic $\left(\lg P_{o w}=2.5 \div 3.5\right)$, stable in water-organic media (stability constants logarithm $\lg \beta=15-18$ ) and have a non-electrolyte nature. Voltammetry analysis was used to determine the first oxidation peak $\left(E_{p a^{1}}, V\right)$ as a thermodynamic criterion of compounds' reducing ability. It was found that complexes with ortho-diphenol derivatives possess stronger reducing ability then the complexes with meta-diphenol. Antimicrobial activity of Ni(II) complexes against Mycobacterium smegmatis and Candida albicans were evaluated. Intricate dependence between reducing ability and bactericidal activity was found.
\end{abstract}

Keywords: Nickel(II) complexes, ortho-diphenol derivatives, meta-diphenol derivatives, lipophilicity, voltammetry, antimicrobial activity

\section{INTRODUCTION}

According to the current epidemiological situation, 8 million new cases of Tuberculosis infection caused by Mycobacterium tuberculosis emerge annually [1]. One of the biggest issues in tuberculosis controlling is the emergence of extensively drug-resistant and totally drug-resistant Mycobacterium spp., sustainable to commonly used antimycobacterial agents [2]. Consequently, there is a pressing need to develop new antibacterials with novel mechanisms of action, rapid antimicrobial activity, and safety.

Phenol and its derivatives are well-known in medical practice [3]. The hydroxyl groups attached to an aromatic ring ensure phenol activity in radical and redox processes which explains a wide range of exhibited properties (enzymes inhibitory, antioxidant, antimicrobial, fungicide, antimalarial, anticancer, etc.) [4]. When applied to Mycobacterium spp., it was shown that phenol derivatives disrupt electron transport chain activity, what significantly affects the pathogens survival and virulence [5-7].

Nowadays, the main drawback limiting the use of phenol derivatives is their toxicity. This issue might be overcome by the introduction of substituents into the benzene ring and metal complexation, which change the hydrophilic-lipophilic properties of a compound, allowing one not only to achieve an optimal antimicrobial effect, but also to broaden the activity spectrum of these derivatives and decrease their toxicity [8-11].
Unlike many antibiotics, metal complexes with phenolic derivatives can realize several mechanisms of biocidal action mainly caused by the metal ions, what makes a probability of pathogens' resistance development negligibly small. Besides, bioactive metal complexes also have other advantages over antibiotics: a low induction of resistance in many pathogenic microorganisms against ions of transition metals, a broad spectrum of activity (antibacterial, antifungal and antiviral), and safety in therapeutic doses (due to the oligodynamic effect of transition metal ions) [12].

In this paper, we discussed the presumed interconnection of antimycobacterial and anticandidal activities against Mycobacterium smegmatis and Candida albicans, redox properties and lipophilicity of $\mathrm{Ni}$ (II) complexes with ortho- and meta-diphenol derivatives. Nickel was chosen as the coordination center due to its involvement in hydrolytic and redox processes in vivo, as well as in some enzymes (urease, carbon monoxide dehydrogenase, acetyl-CoA synthetase, superoxidedismythase etc.) functioning [13].

\section{EXPERIMENTAL PART}

2.1 Synthesis of the Ni(II) complexes with orthoand meta-diphenol derivatives

Ni(II) complexes with 3-(X-1-ylmethyl)-5tritylbenzene-1,2-diol (HL $\left.\mathrm{HL}^{\mathrm{I}} \mathrm{HL}^{\mathrm{V}}\right)$ and 2-(X-1ylmethyl)-4,6-di-tert-bytulbenzene-1,3-diol (HL ${ }^{\mathrm{VI}}$ -

*nabebinak@gmail.com 
$\mathrm{HL}^{\mathrm{X}}$ ) were $\mathrm{X}$ is pyrrolidin $\left(\mathrm{HL}^{\mathrm{I}}, \mathrm{HL}^{\mathrm{VI}}\right)$, piperidin $\left(\mathrm{HL} \mathrm{L}^{\mathrm{II}}\right.$, $\mathrm{HL}^{\mathrm{VII}}$ ), azepan (HL $\left.{ }^{\mathrm{III}}, \mathrm{HL}^{\mathrm{VIII}}\right)$, morpholinomethyl (HL ${ }^{\mathrm{IV}}$, $\left.\mathrm{HL}^{\mathrm{IX}}\right)$, 4- methylpiperazin $\left(\mathrm{HL}^{\mathrm{V}}, \mathrm{HL}^{\mathrm{X}}\right)$ were synthesized according to [14].

\subsection{Physico-chemical characterization}

The stability constants of $\mathrm{Ni}(\mathrm{II})$ ions with diphenol derivatives were investigated by means of potentiometric titration in a water-ethanol medium, using the Microprocessor laboratory ion meter I-16oMP, under argon atmosphere and constant ionic strength. The elemental composition of compounds was found according to a method reported elsewhere [15]. The molar conductivity values of $\mathrm{Ni}(\mathrm{II})$ complexes' solutions $\left(10^{-3} \mathrm{~mol}^{*} \mathrm{~L}^{-1}\right)$ in acetonitrile were measured using the TESLA BMS91 conductometer. The $\mathrm{X}$-ray diffraction analysis (XRD) was carried out using DRON-2 (CuK ${ }_{\alpha}$-emission). The redox-properties of $\mathrm{Ni}$ (II) complexes were evaluated by the means of the cyclic voltammetry method in the potential range from -2.2 to $+2.2 \mathrm{~V}$, using a de-aerated acetonitrile solution of these compounds [16-19]. The lipophilicity test was made by determining the $n$-octanol/water partition coefficient $\left(P_{\text {ow }}\right)[20]$.

\subsection{The structure and composition of the} coordination core

For IR, UV-vis spectrometry data, as well as computational details for $\mathrm{Ni}$ (II) complexes with abovementioned ligands see Ref. [21-22].

\subsection{Antibacterial assay}

The antimicrobial activity of the complexes under study against Mycobacterium smegmatis and Candida albicans was tested in vitro using the method of twofold serial dilutions in liquid nutrient media described elsewhere [23]. In contrast to another test methods, the composition of these media provide favorable conditions for microbial strains growing and do not affect or destroy $\mathrm{Ni}(\mathrm{II})$ complexes during testing. It was determined as the lowest concentration of a compound which inhibits the visible microbial growth, i.e., the minimum inhibitory concentration (MIC, $\mu \mathrm{mol} \cdot \mathrm{ml}^{-1}$ ).

\section{RESUlTS AND DISCUSSION}

Potentiometric titration analysis shows that Ni(II) ions form stable complexes with both ortho- and metadiphenol derivatives with general stability constants found to be $\lg \beta=15 \div 18$. Based on elemental absorption, the spectroscopy composition of the compounds corresponds to general formula $\mathrm{NiL}_{2}$. Molar conductivity values $\left(\Lambda_{\mathrm{M}} \leq 80 \mathrm{~cm}^{2 *} \mathrm{Ohm}^{-1 *} \mathrm{~mol}^{-1}\right)$ point to the nonelectrolyte nature of investigated $\mathrm{Ni}(\mathrm{II})$ complexes [24]. According to the XRD data, all complexes are found to be amorphous with halo diffraction patterns in the $2 \theta$ range from $10^{\circ}$ to $20^{\circ}$. Thermogravimetric analyses showed that $\mathrm{NiL}_{2}$ complexes are stable up to $150^{\circ} \mathrm{C}$. Their decomposition in the temperature range from $200^{\circ}$ to $800^{\circ} \mathrm{C}$ is accompanied with ligand destruction and the formation of nickel(II) oxide as the final product. No peaks pointing to the presence of the solvent molecules in the coordination core were found. The composition and structure analysis of the coordination core done by means of IR, UV-vis and EPR spectroscopy was discussed in [21-22]. $\mathrm{NiL}_{2}$ complexes with abovementioned diphenol derivatives have distorted square-planar geometry with two diphenol molecules in monoanionic form chelating to the central $\mathrm{Ni}$ (II) ion (Figure 1, 2).

Since one of the main requirements for antimicrobials is their high ability to penetrate cellular walls and membranes, complexes' lipophilicity should be considered when developing these bioactive compounds. It was found that the highest values of the $n$-octanol/water partition coefficient $\left(\lg P_{\mathrm{ow}}=3.4-3.5\right)$ belong to $\mathrm{Ni}(\mathrm{II})$ complexes of meta-diphenols, containing piperidine $\left(\mathrm{Ni}\left(\mathrm{L}^{\mathrm{VII}}\right)_{2}\right)$, azepan $\left(\mathrm{Ni}\left(\mathrm{L}^{\mathrm{VIII}}\right)_{2}\right)$ and morpholine $\left(\mathrm{Ni}\left(\mathrm{L}^{\mathrm{IX}}\right)_{2}\right)$ moiety. The complexes with ortho-diphenols $\mathrm{Ni}\left(\mathrm{L}^{\mathrm{I}}\right)_{2}-\mathrm{Ni}\left(\mathrm{L}^{\mathrm{V}}\right)_{2}$ are characterized by lower lipophilicity parameters $\left(\lg P_{\mathrm{ow}}=2.9 \div 3.3\right)$. The lessened lipophilicity $\left(\lg P_{\mathrm{ow}}=2.5 \div 2.6\right)$ belongs to $\mathrm{Ni}(\mathrm{II})$ complexes of meta-diphenols, containing pyrrolidine $\left(\mathrm{Ni}\left(\mathrm{HL}^{\mathrm{VI}}\right)_{2}\right)$ and 4-methylpiperazine $\left(\mathrm{Ni}\left(\mathrm{L}^{\mathrm{X}}\right)_{2}\right)$ moiety. The lipophilicity values of $\mathrm{Ni}(\mathrm{II})$ complexes suggest their potential ability for transmembrane transfer and are also important for the assessment of their bioavailability as well as their antimicrobial activity [25].

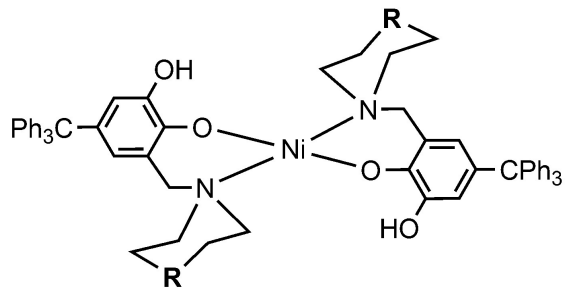

Figure 1. Structure of $\mathrm{Ni}\left(\mathrm{L}^{\mathrm{I}}\right)_{2}-\mathrm{Ni}\left(\mathrm{L}^{\mathrm{V}}\right)_{2}$ complexes

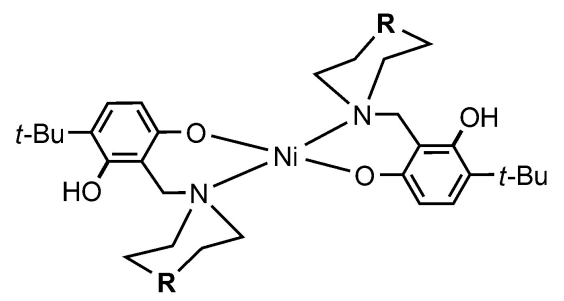

Figure 2. Structure of $\mathrm{Ni}\left(\mathrm{L}^{\mathrm{VI}}\right)_{2}-\mathrm{Ni}\left(\mathrm{L}^{\mathrm{X}}\right)_{2}$ complexes

Redox processes involving the compounds under study can be reversible or irreversible. That is why the potential value for the first oxidation peak $\left(E_{\mathrm{pa}}{ }^{1}, \mathrm{~V}\right)$ was taken as a criterion to compare the reducing ability of these compounds of the same type, and the more cathodic the value, the more active the compound as a reductant [26]. MIC values are given in $\mu \mathrm{mol} \cdot \mathrm{ml}^{-1}$ to 
reveal a correlation between the antimicrobial activity and reducing ability of the compounds.

According to the voltammetry data, the co-location of substituents considerably affects the redox potential of investigated compounds. The peak potential values of complexes with ortho-phenols are $0.55 \div 0.63 \mathrm{~V}$, what is in average $0.2 \mathrm{~V}$ lower, than those for metadiphenols $\left(E_{\mathrm{pa}^{1}}=0.68-0.80 \mathrm{~V}\right)$. It might be concluded that complexes with ortho-diphenol derivatives have stronger reducing ability. This finding is in line with literature, where it was shown that ortho-diphenols have higher activity in biochemical reactions, namely cytochrome $c$ reduction in comparison with metadiphenols due to their ability to form a thermodynamically stable quinone structure.

Antimicrobial assay shows that Ni(II) complexes possess a high and moderate level of bactericidal activity against Mycobacterium smegmatis and Candida albicans, comparable to those of some standard antibiotics (Table 1).

Table 1. MIC values $\left(\mu \mathrm{mol} \cdot \mathrm{ml}^{-1}\right)$, lipophilicity and first peak potentials (V) of $\mathrm{Ni}(\mathrm{II})$ complexes with ortho-diphenol $\left(\mathrm{Ni}\left(\mathrm{L}^{\mathrm{I}}\right)_{2}-\mathrm{Ni}\left(\mathrm{L}^{\mathrm{V}}\right) 2\right)$ and meta-diphenol $\left(\mathrm{Ni}\left(\mathrm{L}^{\mathrm{VI}}\right) 2-\mathrm{Ni}\left(\mathrm{L}^{\mathrm{X}}\right)_{2}\right)$ derivatives

\begin{tabular}{|l|c|c|c|c|}
\hline \multicolumn{1}{|c|}{ Compound } & $\begin{array}{c}\text { Mycobact. } \\
\text { smegmatis }\end{array}$ & $\begin{array}{c}\text { Candida } \\
\text { albicans }\end{array}$ & $\begin{array}{c}\lg P_{\mathrm{o}} \\
\mathrm{w}\end{array}$ & $\begin{array}{c}E_{\mathrm{pa}}{ }^{1} \\
V\end{array}$ \\
\hline $\mathrm{Ni}\left(\mathrm{L}^{\mathrm{I}}\right) 2$ & 0.054 & 0.054 & 3.2 & 0.60 \\
\hline $\mathrm{Ni}\left(\mathrm{L}^{\mathrm{II}}\right) 2$ & 0.051 & 0.051 & 2.9 & 0.55 \\
\hline $\mathrm{Ni}\left(\mathrm{L}^{\mathrm{III}}\right) 2$ & 0.051 & 0.051 & 3.3 & 0.57 \\
\hline $\mathrm{Ni}\left(\mathrm{L}^{\mathrm{IV}}\right) 2$ & 0.052 & 0.052 & 3.3 & 0.63 \\
\hline $\mathrm{Ni}\left(\mathrm{L}^{\mathrm{V}}\right) 2$ & 0.025 & 0.050 & 3.3 & 0.58 \\
\hline $\mathrm{Ni}\left(\mathrm{L}^{\mathrm{VI}}\right) 2$ & 0.019 & 0.037 & 2.6 & 0.77 \\
\hline $\mathrm{Ni}\left(\mathrm{L}^{\mathrm{VII}}\right) 2$ & 0.013 & 0.100 & 3.4 & 0.79 \\
\hline $\mathrm{Ni}\left(\mathrm{L}^{\mathrm{VIII}}\right) 2$ & 0.004 & 0.138 & 3.5 & 0.76 \\
\hline $\mathrm{Ni}\left(\mathrm{L}^{\mathrm{IX}}\right) 2$ & 0.004 & 0.004 & 3.4 & 0.68 \\
\hline $\mathrm{Ni}\left(\mathrm{L}^{\mathrm{X}}\right) 2$ & 0.017 & 0.138 & 2.5 & 0.80 \\
\hline Streptomycin & 0.011 & - & - & - \\
\hline Tetracycline & 0.014 & - & - & - \\
\hline Isoniazid & 0.009 & - & - & - \\
\hline Nystatin & - & 0.007 & - & - \\
\hline Amphotericin & - & 0.003 & - & - \\
B & - & 0.043 & - & - \\
\hline Terbinafine & - & & & \\
\hline & &
\end{tabular}

As it is shown, complexes $\mathrm{Ni}\left(\mathrm{L}^{\mathrm{I}}\right)_{2}-\mathrm{Ni}\left(\mathrm{L}^{\mathrm{V}}\right)_{2}$ evince a moderate level of activity against both mycobacterial and fungi strains. Surprisingly, $\mathrm{Ni}\left(\mathrm{L}^{\mathrm{VI}}\right)_{2}-\mathrm{Ni}\left(\mathrm{L}^{\mathrm{X}}\right)_{2}$ complexes show a high activity against mycobacterial and a nonuniform activity against fungi. $\mathrm{Ni}\left(\mathrm{L}^{\mathrm{IX}}\right)_{2}$ complex with the strongest bactericidal action has the strongest reducing ability of $0.68 \mathrm{~V}$ from all the $\mathrm{Ni}\left(\mathrm{L}^{\mathrm{VI}}\right)_{2}-\mathrm{Ni}\left(\mathrm{L}^{\mathrm{X}}\right)_{2}$ complexes. To explain these findings, it is important to notice that the redox potential is a thermodynamic criterion of an electrochemical reaction being possible, while the ability of redox-active compounds to interact with biomolecules of microorganisms has a more intricate dependence on the structure and physicochemical properties thereof.

According our previous finding [9], an acute toxicity of transition metal complexes with benzene derivatives is comparable to those of standard antibiotics ampicillin and streptomycin $\left(\mathrm{LD}_{50}=1400-\right.$ $3400 \mathrm{mg} / \mathrm{kg}$ ) [27].

\section{CONCLUSION}

According to the elemental analysis, TG/DTA and spectroscopic data, a general formula of the complexes is $\mathrm{NiL}_{2}$ with ligands coordinated in a bidentate manner through $\mathrm{O}$ and $\mathrm{N}$ atoms with the formation of a distorted square-planar coordination core. Complexes are amorphous, water insoluble non-electrolyte $\left(\Lambda_{\text {mol }}<120 \Omega^{-}\right.$ ${ }^{1} \mathrm{~cm}^{2} \mathrm{~mol}^{-1}$ ) compounds, stable in water-organic media (general stability constant $\lg \beta=15 \div 18$ ). Lipophilicity parameters of both $\mathrm{Ni}\left(\mathrm{L}^{\mathrm{I}}\right)_{2}-\mathrm{Ni}\left(\mathrm{L}^{\mathrm{V}}\right)_{2}\left(\lg P_{\mathrm{ow}}=2.9-3.3\right)$ and $\mathrm{Ni}\left(\mathrm{L}^{\mathrm{VI}}\right)_{2}-\mathrm{Ni}\left(\mathrm{L}^{\mathrm{X}}\right)_{2} \quad\left(\lg P_{\mathrm{ow}}=2.5-3.5\right)$ complexes suggest their potential ability for the transmembrane transfer. By means of the cyclic voltammetry method, redox properties of the complexes were evaluated. It was found that $\mathrm{Ni}(\mathrm{II})$ complexes with meta-diphenol derivatives have $E_{\mathrm{pa}^{1}}{ }^{1}$ values on average $0.2 \mathrm{~V}$ higher than the complexes with ortho-diphenols. A complicated regularity between the antimicrobial activity and redox properties of complexes has been noticed. Our findings point to the conclusion that activity against pathogens depends not only on the thermodynamic possibility of redox process, but also on other physicochemical characteristics (in particular, lipophilicity) and structure peculiarities of compounds.

\section{REFERENCES}

1. B. J. Marais, "The global tuberculosis situation and the inexorable rise of drug-resistant disease," Adv. Drug Deliv. Rev., vol. 102, pp. 3- 9, Jul. 2016.

DOI: $10.1016 /$ j.addr.2016.01.021

PMid: 26855302

2. M. S. Jassal, W. R. Bishal, "Extensively drug-resistant tuberculosis," Lancet Infect. Dis., vol. 9, no. 1, pp. $19-30$, Jan. 2009.

DOI: 10.1016/S1473-3099(08)70260-3

PMid: 18990610

3. G. McDonnell, A. D. Russell, "Antiseptics and disinfectants: activity, action, and resistance," Clin. Microbiol. Rev., vol. 12, no. 1, pp. 147 - 179, Jan. 1999.

DOI: 10.1128/CMR.12.1.147

PMid: 9880479 PMCid: PMC88911

4. P.J. O'Brien, "Molecular mechanisms of quinone cytotoxicity," Chem. Biol. Interact., vol. 80, no. 1, pp. $1-41,1991$.

DOI: 10.1016/0009-2797(91)90029-7

PMid: 1913977

5. J. Cohen, "Approval of novel TB drug celebrated-with restraint," Science, vol. 339, no. 6116, pp. 130, Jan. 2013. DOI: $10.1126 /$ science.339.6116.130 PMid: 23307714

6. D. T. Hoagland, J. Liu, R. B. Lee, R. E. Lee, "New agents for the treatment of drug-resistant Mycobacterium tuberculosis," Adv. Drug Deliv. Rev., vol. 102, pp. $55-72$, Jul. 2016.

DOI: 10.1016/j.addr.2016.04.026

PMid: 27151308 PMCid: PMC4903924

7. K. Pethe et al., "Discovery of Q203, a potent clinical candidate for the treatment of tuberculosis," Nat. Med., vol. 19, no. 9, pp. 1157 - 1160, Sep. 2013.

DOI: $10.1038 / \mathrm{nm} .3262$ 
PMid: 23913123

8. N. V. Loginova et al., "Redox-active antimicrobial metal complexes with sterically hindered o-diphenol and o-aminophenol derivatives," in Biometals: Molecular Structures, Binding Properties and Applications, G. Blanc, D. Moreau, Eds., 1st ed., New York (NY), USA: Nova Science Publisher's, 2010, ch. 3, pp. 59- 90.

9. N. V. Loginova et al., "Pharmacologically active of benzene derivatives of synthesis, complexation with biometals and biological evaluation sterically hindered 1,2-dihydroxybenzene and o-aminophenol derivatives," in Benzene and its derivatives: New Uses and Impacts on Environment and Human Health, G. Tranfo, Eds., 1st ed., New York (NY), USA: Nova Science Publisher's, 2012, ch. 2 , pp. $23-68$.

10. N. V. Loginova et al., "Redox-active silver(I) complexes with sterically hindered 1,2-dihydroxybenzene derivatives: reduction of cytochrome $\mathrm{c}$ and antimicrobial activity," in Cytochromes b and c: Biochemical Properties, Biological Functions and Electrochemical Analysis, R. Thom, Eds., 1st ed., New York (NY), USA: Nova Science Publisher's, 2014, ch. 5, pp. 121 - 171.

11. N. V. Loginova et al., "Redox-active metal complexes with cycloaminomethyl derivatives of diphenols: antibacterial and SOD-like activity, reduction of cytochrome c," in Antibacterials: Synthesis, Properties and Biological Activities, E. Collins, Eds., 1st ed., New York (NY), USA: Nova Science Publisher's, 2017, ch. 6, pp. $143-180$.

12. A. B. G. Lansdown, "Silver in health care: antimicrobial effects and safety in use," in Biofunctional Textiles and the Skin. Curr Probl Dermatol., vol. 33, U. C. Hipler, P. Elsner, Eds., 1st ed., Basel, Switzerland: Karger, 2006, pp. $17-34$.

DOI: $10.1159 / 000093928$

13. J. C. Fontecilla-Camps, "Biological Nickel," in Bioinorganic Chemistry: Trace Element Evolution from Anaerobes to Aerobes, R. J. P. Williams, Eds., 1st ed., Berlin Heidelberg, Germany: Springer-Verlag, 1998, ch. 1, pp. $1-30$.

Retrieved from:

http://library.lol/main/C23907F55.3832C6853F8.3F576E C92BA5

Retrieved on: Jan. 11, 2020

14. H. I. Harbatsevich et al., "Nickel(II) complexes with "non innocent' ligands - cycloaminomethyl derivatives of 1,2-dihydroxybenzene: sod-like and antimicrobial activity," Radiat. Appl., vol. 2, no. 2, pp. 129 - 133, Jan. 2017.

DOI: $10.21175 /$ RadJ.2017.02.027

15. В.А. Климова, Основные микрометоды анализа органических соединений, 2-й изд., Москва, Россия: Химия, 1975, с. 224.

(V. A. Klimova, The basis of micro methods of organic compounds analysis, 2nd ed., Moscow, Russia: Chemistry, 1975, p. 224.)

Retrieved from:

http://libgen.rs/book/index.php?md $5=2 \mathrm{DCEF}_{5}$ ED 5 CEE 7BD9F0987A29254DA260 Retrieved on: Nov. 29, 2019

16. N. V. Loginova et al., "Redox-active metal(II) complexes of sterically hindered phenolic ligands: Antibacterial activity and reduction of cytochrome c," Polyhedron, vol. 29, no. 6, pp. 1646 - 1652, Apr. 2010. DOI: $10.1016 /$ j.poly.2010.02.007

17. N. V. Loginova et al., "Redox-active metal(II) complexes of sterically hindered phenolic ligands: Antibacterial activity and reduction of cytochrome c. Part II. Metal(II) complexes of o-diphenol derivatives of thioglycolic acid," Polyhedron, vol. 30, no. 15, pp. 2581 - 2591, Sep. 2011.
DOI: 10.1016/j.poly.2011.07.008

18. N. V. Loginova et al., "Redox-active metal(II) complexes of sterically hindered phenolic ligands: Antibacterial activity and reduction of cytochrome c. Part III. Copper(II) complexes of cycloaminomethyl derivatives of o-diphenols," Polyhedron, vol. 57, pp. 39-46, Jul. 2013. DOI: 10.1016/j.poly.2013.04.015

19. N. V. Loginova et al., "Redox-active metal complexes of sterically hindered phenolic ligands: Antibacterial activity and reduction of cytochrome c. Part IV. Silver(I) complexes with hydrazone and thiosemicarbazone derivatives of 4,6-di-tert-butyl-2,3dihydroxybenzaldehyde," Polyhedron, vol. 88, pp. 125 - 137, Mar. 2015. DOI: $10.1016 /$ j.poly.2014.12.014

20. A. Leo, C. Hancsh, D. Elkins, "Partition coefficients and their uses," Chem. Rev., vol. 71, no. 6. pp. $525-616$, Dec. 1971.

DOI: $10.1021 / \mathrm{cr} 60274 a 001$

21. N. V. Loginova et al., "Interaction of cytochrome $\mathrm{c}$ with redox-active dihydroxybenzene-containing antimicrobials: application to antioxidant characterization," in Cytochrome C: Roles and Therapeutic Implications, N. Arias, Eds., New York (NY), USA: Nova Science Publisher's, 2019, ch. 2, pp. $51-87$.

22. К. А. Набебина, Н. В. Логинова, Т. В. КовальчукРабчинская, Г. А. Ксендзова, Н. П. Осипович, "Синтез и свойства редокс-активных комплексов $\mathrm{Ni}(\mathrm{II})$ с производными дигидроксибензола," Свиридовские чтения: сборник статей, но. 15, стр. 184 - 193, 2019. (K. A. Nabebina, N. V. Loginova, T. V. Koval'chukRabchinskaya, G. A. Ksendzova, N. P. Osipovich, "Synthes and properties of redox active Ni(II) complexes with dihydroxybenzene derivatives" Sviridov Readings: a collection of paper, no. 15, pp. 184 - 193, 2019.) Retrieved from:

https://elib.bsu.by/handle/123456789/237518 Retrieved on: Sep. 20, 2019

23. D. Amsterdam, Antibiotics in Laboratory Medicine, 6th ed., Philadelphia (PA), USA: Lippincott Williams Wilkins, 2014.

Retrieved from:

http://library.lol/main/C93B8401A35AE671BFE016Fo6 AE8C $51 \mathrm{~F}$

Retrieved on: Sep. 13, 2019

24. W. J. Geary, "The use of conductivity measurements in organic solvents for the characterisation of coordination compounds," Coord. Chem. Rev., vol. 7, no. 1, pp. 81 - 122, Oct. 1971.

DOI: 10.1016/Soo10-8545(00)80009-0

25. M. J. Waring, "Lipophilicity in drug discovery," Expert Opin. Drug Discov., vol. 5, no. 3, pp. 235 - 248, Mar. 2010.

DOI: $10.1517 / 17460441003605098$

PMid: 22823020

26. F. Scholz, Electroanalytical Methods: Guide to Experiments and Applications, vol. 1, 2nd ed., Berlin, Germany: Springer-Verlag, 2010. Retrieved from:

http://library.lol/main/9D15B8E76FB88030D73BBEEo C7649607

Retrieved on: Feb. 10, 2020

27. G. Lancini, F. Parenti, Antibiotics: An Integrated View, 1st ed., New York (NY), USA: Springer-Verlag, 1982.

Retrieved from: http://library.lol/main/28AB26730E73E50010156D3FC $\mathrm{O}_{4} \mathrm{~B}_{3} \mathrm{BB} 7$

Retrieved on: Dec. 25, 2019 